\title{
Three Times Yearly
}

National Cancer Institute

\section{Source}

National Cancer Institute. Three Times Yearly. NCI Thesaurus. Code C98860.

Three times per year. 